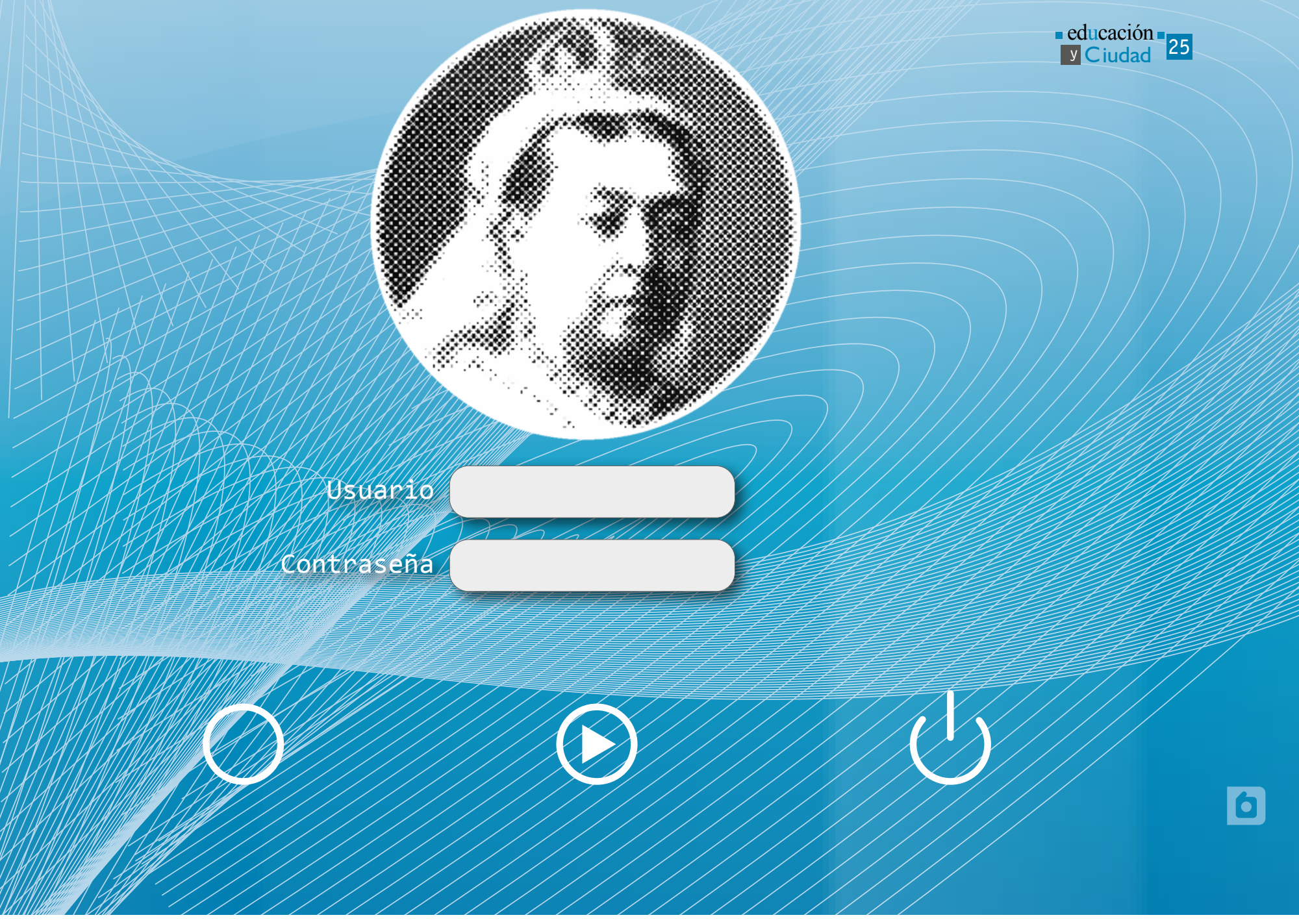

\title{
La Web Victoriana y el Curso Victoriano Wiki: comparación de la eficacia educativa de tareas idénticas en la Web 1.0 y la Web 2.0
}

The victorian web and the victorian course wiki: comparing the educational effectiveness of identical assignments in web 1.0 and web 2.0

A Web Victorian eo Curso Wiki: comparando a eficácia educativa de tarefas idênticas em Web 1.0 e Web 2.0

George P. Landow george@landow.com 


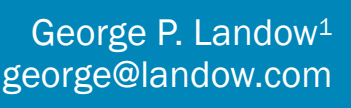

george@landow.com
1 Catedrático de la Universidad de Brown, crítico y teórico de literatura electrónica, así como pionero en el análisis de las características y los efectos del uso del hipertexto y los hipermedia. Department of English, Box 1852, Brown University, Providence, Rhode Island 02912, USA.

Fecha de recepción: 14 de octubre de 2013 / Fecha de aprobación. 8 de noviembre de 2013

\section{La Web Victoriana y el Curso Victoriano Wiki: comparación de la eficacia educativa de tareas idénticas en la Web 1.0 y la Web 2.0}

\section{Resumen}

El autor del presente texto pronunció un discurso en Porto, Portugal, para el WikiSym 2008, realizado en septiembre del mismo año, titulado "Cuando una Wiki no es una Wiki: veinte años de la Web Victoriana", en el que argumentó que los 45.000 documentos que conforman la www.victorianweb.org funcionan como una Wiki moderada y que, por lo tanto, la Web 1.0 puede funcionar para propósitos educativos tan bien como la Web 2.0, además, afirmó que ha sido así durante muchos años.

Con esto en mente, Landow asumió el reto de emplear una Wiki real y para hacerlo enseñó el mismo curso, con las mismas tareas estudiantiles semanales, durante los siguientes dos años (2009, 2010); en 2009 utilizó el sitio Web antes mencionado, mientras que en 2010 empleó una Wiki cerrada, protegida con contraseña. En el presente artículo se realiza una breve descripción de la composición, historia y autoría de la Web Victoriana y de los componentes claves que han existido en múltiples ambientes hipermedia desde su creación en 1988, para el proyecto de Intermedia de la Universidad de Brown. Además, se presenta la tarea realizada, explicando sus metas, para finalmente establecer los resultados de esta experiencia haciendo un listado de las ventajas y desventajas del uso de la Wiki para los docentes, estudiantes y el sitio Web correspondiente.

Palabras clave: hipertexto, hipermedia, Wiki, educación, conectividad.
The victorian web and the victorian course wiki: comparing the educational effectiveness of identical assignments in web 1.0 and web 2.0

\section{Summary}

In September 2008, the author delivered a keynote at WikiSym2008, in Porto, Portugal entitled "When a Wiki is not a Wiki: Twenty Years of the Victorian Web" in which he argued that the 45,000 documents that then made up www. victorianweb.org function as a moderated wiki and that, therefore, Web 1.0 can function for educational purposes much as Web 2.0 - and has done so for many years. Challenged to employ an actual wiki, Landow taught the same course with the same weekly student assignments in successive years $(2009,2010)$, the first using the website, the second a closed, password-protected wiki. After briefly describing the composition, history, and authorship of the Victorian Web, key parts of which have existed in multiple hypermedia environments since their creation in 1988 for the Brown University Intermedia project, it presents the assignment, explains its goals, and then sets forth the results of this experience, listing advantages and disadvantages of using the wiki for instructors, students, and the related website.

Key words: hypertext, hypermedia, wiki, education, connectivity, assignments, evaluation, web 2.0, the Victorian Web, student-centered discussion, student-led discussion, expository writing.

Palabras clave: hypertext, hypermedia, wiki, education, connectivity, assignments, evaluation, web 2.0, the Victorian Web, student-centered discussion, student-led discussion, expository writing.

\section{A Web Victorian eo Curso Wiki: comparando a eficácia educativa de tarefas idênticas em Web 1.0 e Web 2.0}

\section{Resumo}

0 autor deste texto fez um discurso em Porto, Portugal, para WikiSym 2008, realizado em setembro do mesmo ano, intitulado " Quando um Wiki não é um Wiki: Vinte anos da Web vitoriana, " no qual argumentava que 45.000 documentos que compõem a função Wiki www. victorianweb.org como um moderado e, portanto, a Web 1.0 pode funcionar para fins educacionais, bem como web 2.0, também disse que ele tem sido assim por muitos anos. Com isto em mente, Landow assumiu o desafio de usar um verdadeiro Wiki e torná-lo ensinado o mesmo curso com as mesmas atribuições do estudante semanais ao longo dos próximos dois anos $(2009,2010)$ e em 2009 usou o site acima, e que em 2010 empregava um Wiki fechado, protegido por senha. Neste artigo uma breve descrição da composição , história e autoria da Web vitoriana e os principais componentes que já existem em vários ambientes de hipermídia desde a sua criação em 1988, para a proposta da Universidade Middle Brown é feita. Além disso, o trabalho feito, explicando seus objetivos, para finalmente estabelecer os resultados desta experiência , listando as vantagens e desvantagens de usar 0 Wiki para professores, estudantes eo site correspondente é apresentado.

Palabras clave: hipertexto, hipermídia, Wiki, a educação, a conectividade. 


\section{Introducción}

En septiembre de 2008 presenté una ponencia en Porto, Portugal, para el WikiSym 2008, durante la Conferencia Internacional Anual de la Association for Computing Machinery, titulada "Cuando una Wiki no es una Wiki: veinte años de la Web Victoriana”, en ella argumenté cómo los 45.000 documentos que conforman la www.victorianweb.org funcionan como una Wiki moderada y que, por lo tanto, la Web 1.0 puede funcionar para propósitos educativos tan bien como la Web 2.0, pues ha sido así durante muchos años.

Tanto los miembros del comité del programa, como la audiencia (ver reconocimientos), consideraron oportuno sugerir el uso del software Wiki real y comparar los resultados obtenidos con los arrojados por su uso en la Web Victoriana. Aceptando el desafío, comencé por comparar el rendimiento de un grupo de estudiantes y la carga laboral del docente, en dos interacciones en una clase de inglés de la Universidad Brown, Inglés 0600J S01 [CRN 25281], titulada Enojados, Misticos, Monstruos, Profetas y Pervertidos, que, a pesar de su título sensacionalista, cuenta con la forma de una encuesta muy tradicional de la poesía Británica Victoriana de ficción y no ficción.

Las versiones desarrolladas para los cursos de la primavera de 2009 y 2010, tuvieron esencialmente las mismas inscripciones y una distribución similar de estudiantes. A la manera típica de la Universidad de Brown, se escogieron estudiantes de primero y segundo año, incluidos los de octavo año del programa de medicina de Brown, y un puñado de estudiantes de tercer y cuarto año de pregrado en física y ciencias sociales, algunos de los cuales tuvieron un desempeño sobresaliente en la clase, recibiendo A como nota, a pesar de que Inglés fue su primera clase de literatura universitaria.
Con el fin de crear un grupo de control para la evaluación prevista en la primavera del 2009, se enseñó la clase antes de usar la Web Victoriana. Al año siguiente (primavera de 2010), fue utilizada la misma clase con un syllabus idéntico, empleando nuevamente la Web Victoriana para las lecturas y las experiencias de los estudiantes o las lecturas contextuales; sin embargo, en esta ocasión los estudiantes plantearon sus tareas de discusión semanal de preguntas, que sirven como núcleo de la clase (las cuales se describen a continuación), directamente en una Wiki protegida con contraseña creada con el software Confluence de Atlassian, escogido porque fue el utilizado por el Grupo de Tecnología Instruccional de la Universidad de Brown y porque algunos estudiantes estaban familiarizados con él.

Debido a que los experimentos, que utilizaron los mismos materiales en tres entornos hipermedia muy diferentes, habían mostrado claramente que los estudiantes entendían que estos sistemas contenían el mismo material, o como ellos lo expresan, los mismos hipertextos (Landow y Kahn, 1992), fue necesario ver si los estudiantes tenían experiencias similares y obtenían lo mismo educacionalmente cuando utilizaran tanto una Wiki, como un sitio Web moderado. Gracias a que el trabajo más reciente ha revelado que los estudiantes hacen un uso mucho mayor de la conectividad esencial del hipertexto, cuando los docentes explicaban las potencialidades de las tecnologías de la información (Landow y Miller 2010), también resultó importante analizar si eso afectaba el uso de la Wiki como lo había hecho su uso de la Web Victoriana.

\section{Organización del presente artículo}

Para poner los resultados de la comparación en el contexto adecuado, la siguiente discusión: a) Describe brevemente la composición, historia y autoría de la Web Victoriana, y el núcleo de documentos que han existido en múltiples entornos hipermedia desde su creación, en los inicios de 1988, para el Proyecto In- termedia de la Universidad de Brown (Yankelovich et. al 1988, Hahn et al. 1992, Kahn 1993); b) Presenta la tarea utilizada y los aportes de los estudiantes a la Web Victoriana en 2009 y, para el año siguiente, a la Wiki Victoriana; c) Explica las metas de esta tarea para exponer las ventajas y desventajas del uso de la Wiki. 


\section{The victorian web and the victorian course wikif comparing the educational effectiveness of identical assignments in web 1.0 and web 2.0}

\section{Introduction}

In September 2008, Landow delivered an invited keynote at WikiSym2008, an annual ACM international conference, in Porto, Portugal entitled "When a Wiki is not a Wiki: Twenty Years of the Victorian Web" in which he argued that the 45,000 documents that then made up www.victorianweb.org function as a moderated wiki and that, therefore, Web 1.0 can function much as Web 2.0 and has done so for many years. Members of both the program committee and the audience (see the acknowledgements) invited Landow to use actual wiki software and compare the results of using one to that of using the Victorian Web. Landow accepted the challenge and compared student performance and instructor's workload in two iterations of a Brown University English class, English 0600J S01 [CRN 25281], Madmen, Mystics, Monsters, Prophets, and Perverts, which despite its sensational title takes the form of a quite traditional survey of British Victorian poetry, fiction, and nonfiction.

The Spring 2009 and Spring 2010 versions of the course had essentially the same enrollments and a similar distribution of students. In a manner typical of Brown University, they ranged from first- and second-year students, including those in Brown's 8 -year medical program, and a sprinkling of third- and fourth-year undergraduates from the physical and social sciences, several of whom produced outstanding performances in the class, receiving A grades, even though English 0600J was their first university literature class.

\section{Organization of this paper}

To place the results of the comparison in its proper context, the following discussion (a) briefly describes the composition, history, and authorship of the Victorian Web, the core documents of which have existed in multiple hypermedia environments since their creation in beginning 1988 for the Brown University Interme-
In order to create a control group for the planned evaluation, in Spring 2009 Landow taught the class as before using the Victorian Web. The following year (Spring 2010) Landow taught the same class with an identical syllabus, again used the Victorian Web for readings and the students' background or contextual readings, but students now placed their weekly discussion-question assignments, which serve as the core of the class and which are described below, directly on a password-protected wiki created with Confluence software from Atlassian. Confluence was chosen because this was the software used by Brown University's Instructional Technology Group and some students were familiar with it.

Since experiments with placing the same materials in three very different hypermedia environments had clearly demonstrated that students understood these systems to contain the same material, or as they put it, the same hypertexts (Landow and Kahn, 1992), Landow wanted to see if students using both a Wiki and a moderated website had similar experiences and gained as much educationally. Since more recent work had shown that students made much greater use of the essential connectivity of hypertext when instructors explained the potentials of the information technology (Landow and Miller 2010), Landow also wanted to see if that affected their use of the wiki as it had their use of the Victorian Web.

dia project (Yankelovitch et al. 1988, Hahn et al. 1992, Kahn 1993). Next (b) it presents the assignment used for student contributions in 2009 to the Victorian Web and the following year to the Victorian Wiki. It then (c) explains goals of this assignment, after which (d) it sets forth the advantages and disadvantages of using the wiki. 


\section{La Web Victoriana}

La Web Victoriana es un sitio educativo de internet, académico, sin ánimo de lucro y en continuo crecimiento; hasta marzo 14 de 2011 contenía 52.218 documentos e imágenes que tratan una amplia gama de temas del Siglo XIX, incluyendo literatura, artes y diseño, historia de la ciencia, filosofía, economía religión e historia social y política ${ }^{2}$.

El sitio combina de forma única becas, críticas y reseñas de libros originales, con el trabajo de estudiantes de pregrado y postgrado en instituciones de América del Norte, Europa Continental, el Reino Unido y Asia. Los documentos abarcan desde material legado, que incluye versiones hipertextualizadas de libros fuera de impresión (misc/ books.html), sobre literatura, historia del arte, religión, filosofía e historia, publicados por grandes universidades e impresiones comerciales (por ejemplo, la Clarendon Press, Cornell, Ohio, Princeton, Virginia, y Yale University Press), así como una amplia variedad de textos del Siglo XIX, muchos de los cuales tienen que ver con la ciencia.

Las secciones del sitio sobre arquitectura, artes decorativas, pintura y escultura (art/ index.html), que son particularmente ricas, contienen más de 10.000 fotografías originales e imágenes escaneadas de material sin derechos de autor (por ejemplo, un libro de ilustraciones), además de fotografías escaneadas elaboradas con el permiso de los titulares de los derechos de autor (principalmente galerías y museos). Muchos documentos sobre arte e historia de la arquitectura constan de ensayos sobre trabajos individuales y múltiples fotografías de los mismos, a veces más de una docena (por ejemplo, art/architecture/bentley/1.html). De esta manera, se encuentran las propuestas de evaluaciones de la Web Victoriana para los usos de la hipermedia en la investigación de historia del arte y educación, que data de hace dos décadas en la Academia Británica/Consejo Americano de las sociedades científicas en ciencia y tecnología en las humanidades (Landow 1990).

El sitio también incluye proyectos de multimedia e hipermedia, tales como un pequeño número de imágenes giratorias de esculturas y artes decorativas creadas en el antiguo QuickTime VR y más recientemente $V \mathrm{R}$ Worx 2.5 de la VRToolbox.com (seguir el enlace en sculpture/gilbert/42.html). Los archivos sonoros no sólo incluyen lecturas de poesía sino varias docenas de interpretaciones de salón, baladas, y canciones de música de sala interpre- tadas por Derek V. Scott, profesor de Musicología Crítica de la Universidad de Leeds ( $\mathrm{mt} /$ parlorsongs / index.html).

Por otra parte, el sitio funcionó durante mucho tiempo como un laboratorio o banco de pruebas hipermedia para la educación y la realización de experimentos en la exploración de nuevas formas de discurso académico, tanto en materiales escritos como para entornos hipertextuales; así como para la traducción de materiales tradicionales, tales como los convencionales libros impresos y los artículos.

Aproximadamente 48.000 documentos están en el inglés original, y el resto están traducidos al francés y al español por más de 60 traductores, coordinados por la profesora Asunción López-Varela Azcarte de la Facultad de Filología de la Universidad Complutense de Madrid, y financiados por subsidios de la Universidad y otras agencias de financiamiento de España (Ver Apéndice o).

Aunque la Web Victoriana se concentra en la literatura británica y la historia y cultura de la época que lleva su nombre, también incluye material relevante relacionado con los períodos anteriores y posteriores. Del mismo modo, contiene materiales comparativos de países distintos del Reino Unido. Por ejemplo, las secciones sobre el uso del hierro en la arquitectura (arte / arquitectura / hierro / index.html), las estaciones de ferrocarril (tecnología / ferrocarriles / stations.html); la escultura y la pintura tienen ejemplos de Austria, Australia, República Checa, Francia, Alemania, Hong Kong, Hungría, India, Italia, Malasia, Nigeria, Portugal, Vietnam y Estados Unidos. La sección de estetas, decadentes y simbolistas varía particular y ampliamente (decadencia / index.html).

Con el paso de los años, de su crecimiento y desarrollo continuo, la Web Victoriana ha sido utilizada para una gran variedad de propósitos educativos. Además, es uno de los doce sitios recomendados por el Fondo Nacional para las Humanidades, y de la misma forma cuenta con el voto de confianza de la BBC y los ministerios de educación de Escocia, Francia, Suecia, Australia, entre otros países.

Los materiales que conforman la Web Victoriana se derivan de un pequeño corpus de documentos creados originalmente para un proyecto educativo que precedió a la Red Internacional (World Wide Web). Este proyecto fue financiado por IBM,

2 La URL de la página principal o mapa del sitio es http://www.victorianweb.org/. En aras de la brevedad, las citas de secciones específicas de este gran sitio sólo incluyen la fracción de la URL que sigue a la primaria. Por ejemplo, el mapa del sitio para los 100 autores literarios más discutidos en la página es: (autores / index.html). 


\section{The Victorian Web}

The Victorian Web is an educational, scholarly, non-profit, continually growing Internet site that (as of 14 March 2011) contained 52,218 documents and images on a wide range of nineteenth-century subjects including literature, the arts and design, the history of science, philosophy, religion, economics, and social and political history.

[Note: the URL of the site's homepage or sitemap is http:/ / www. victorianweb.org/. For the sake of brevity, the citations of specific sections of this large site only include the portion of the URL that follows the primary one. For example, the sitemap for the $100+$ literary authors discussed on the site is (authors/index.html).]

This site uniquely combines original scholarship, criticism, and book reviews with work by undergraduate and postgraduate students at institutions in North America, Continental Europe, the U. K., and Asia. Documents range from legacy material, including hypertetxualized versions of out-of-print books (misc/ books.html) on literature, art history, religion, philosophy, and history originally published by major university and commercial presses (e.g., the Clarendon Press, Cornell, Ohio, Princeton, Virginia, and Yale UP) as well as a wide range of nineteenth-century texts, many of which concern science.

The site's sections on architecture, book illustration, decorative arts, painting, and sculpture (art/index.html), which are particularly rich, contain both more than 10,000 original photographs and image scans of out-of-copyright material (e.g., book illustrations) plus scanned photographs of objects made with the permission of copyright holders (major galleries and museums). Many documents concerning art and architectural history consist of both essays on individual works and multiple photographs of them, sometimes more than a dozen (e.g., art/architecture/bentley/1.html). In this way, the Victorian Web tests proposals for the uses of hypermedia in art historical scholarship and education that date back two decades to the British Academy/American Council of Learned Societies conference on scholarship and technology in the humanities (Landow 1990).

The site also includes multimedia and hypermedia projects, such as a small number of rotatable images of sculpture and decorative arts created in the old QuickTime VR and more recently VRToolbox.com's VR Worx 2.5 (follow link in sculpture/gilbert/42.html). Sound files include not only readings of poetry but also several dozen performances of Victorian parlor songs, ballads, and music hall songs performed by Derek V. Sco- $\mathrm{tt}$, Professor of Critical Musicology, University of Leeds (mt/ parlorsongs/index.html).

The site, which has thus long functioned as a laboratory or test bed for hypermedia in education and experiments in exploring new forms of scholarly discourse, both materials written in and for hypertext environments and the translation of legacy materials, such as conventional print books and articles.

Approximately 48,000 documents are in the original English, and the remainder in French and Spanish translation created by more than 60 translators who are coordinated by Professor Asuncion López-Varela Azcarte of the Facultad de Filologia de Universidad Complutense de Madrid and funded by grants from her university and other Spanish granting agencies (see Appendix 6).

Although the Victorian Web concentrates on British literature, history, and culture during the age of Victoria, it includes relevant material related to both earlier and later periods. Similarly, it includes comparative materials from countries outside the United Kingdom. For example, the sections on the use of iron in architecture (art/architecture/iron/index.html), railroad stations (technology/ railways/stations.html), sculpture, and painting have examples from Austria, Australia, the Czech Republic, France, Germany, Hong Kong, Hungary, India, Italy, Malaysia, Nigeria, Portugal, Vietnam, and the United States. The section on Aesthetes, Decadents, and Symbolists ranges particularly widely (decadence/index.html).

Throughout the years of its continual growth and development, it has been used for a range of educational purposes.

The Victorian Web is one of a dozen and a half sites recommended by the National Endowment for the Humanities as well as the BBC and ministries of education in Scotland, France, Sweden, Australia, and other countries.

The materials that form The Victorian Web derive from a small corpus of documents originally created for an educational project that predated the World Wide Web. This project, which was financed by IBM, Apple, and the Annenberg/Corporation for Public Broadcasting, ended in 1990, and since that time these materials have grown as the result of contributions by more than 500 faculty authors from around the world. Between 2000-2008, he University Scholars Programme at the National University of Singapore provided equipment, research assistants. postdoctoral fellowships, and equipment to carry out the project.

For a more complete history of the Victorian Web, see the Appendix. 
Apple y la Annenberg / Corporación para la Difusión Pública, y logró su consolidación en 1990; desde entonces los materiales han crecido paulatinamente como resultado de las contribuciones de más de 500 autores académicos de todo el mundo. Entre
2000 y 2008, el programa de becas universitarias de la Universidad Nacional de Singapur, proporcionó equipo, asistentes de investigación, becas postdoctorales y equipo para llevar a cabo el proyecto ${ }^{3}$.

\section{Tareas realizadas en la Wiki y en la Web Victoriana}

A continuación se presentan las tareas semanales empleadas para la versión de 2009 (Web Victoriana), con base en los aportes de los estudiantes:

"Discusión de preguntas semanales. El curso está basado en gran medida en la discusión de los estudiantes a partir de las tareas semanales de escritura. Estas preguntas de lectura y discusión tienen diversas piezas que resultan necesarias:

- Elegir un pasaje importante de los párrafos 1 a 3, o estrofas cuando se habla de un texto literario, optar por una sola obra cuando se habla de una pintura, dibujo o ejemplo de las artes decorativas.

- Crear una presentación atractiva y una introducción eficaz para el material escogido, que sugiera por qué el lector debería querer seguirlo mientras lo examina de cerca.

- Seguir el pasaje citado, con al menos un párrafo de comentario.

- Realizar 4-5 preguntas, relacionadas principalmente con la técnica y la comparación con otros trabajos, para aquellos que no tienen por qué tener respuestas. A medida que el semestre avance, al menos una pregunta debe incluir una comparación del poema u otro texto discutido con una lectura de la semana anterior.

- Proporcionar un título para su grupo de preguntas e incluir su curso de graduación esperado.

Estos ejercicios, que constituyen la base de la discusión en clase, por lo general me deben ser enviados por correo electrónico antes de las $6 \mathrm{pm}$ del domingo que precede la discusión de la lectura, aunque también pueden ser enviados ocasionalmente el lunes o el martes"4.

La tarea descrita brevemente en otro lugar (Landow 2006 28691) y que ha sido utilizada en ambos espacios para los estudiantes principiantes y para los seminaristas graduados (nota de ejemplo de URLs), tiene los siguientes propósitos o metas educativas:

- Permitir que los estudiantes desarrollen habilidades en la elección de los datos pertinentes que apoyen una discusión o una interpretación.

- Permitir que los estudiantes desarrollen habilidades en la elección de datos que proporcionen la base para una discusión interesante, educativa e informativa con sus compañeros de clase.

- Permitir a los estudiantes hacer introducciones eficaces de los datos, que en esta clase consisten en pasajes de textos de obras literarias. Estas introducciones deberían incluir la razón para citar el texto mientras, al tiempo, se convence a los lectores de que el escritor tiene un orden de la información que presenta ${ }^{5}$.

- Permitir a los estudiantes desarrollar habilidades en la elección de datos que proporcionan una manera efectiva de empezar un ensayo (o para abrir una sección dentro de un ensayo dividido en partes distintas con subtítulos).

- Permitir a los estudiantes desarrollar técnicas para moverse con eficacia desde dichos pasajes importantes del texto citado, hacia las siguientes secciones de sus argumentos.

- Introducir al estudiante a una forma efectiva de evitar el bloqueo del escritor, la dificultad de empezar a escribir cuando se enfrentan a la intimidante superficie en blanco, ya sea en una hoja de papel o en la pantalla.

- Permitir a los estudiantes desarrollar habilidades en la formulación de preguntas basadas en los datos seleccionados. Estas preguntas, que para un público fundamentan la razón por la cual el autor ha elegido el pasaje en primer lugar, sirven en las reuniones de clase como temas de discusión, mientras que en la redacción de ensayos reales, pueden servir de base para las posteriores secciones del argumento.

2 Se recomienda consultar el Apéndice para contar con mayor información sobre la Web Victoriana.

Pueden omitir un sólo grupo de preguntas durante el semestre, y es necesario considerar que es posible no tener una de las últimas semanas de clase (courses/60.2009.html\#writing)".

5 Otras clases de pintura, escultura y artes decorativas en las que los datos se componen de textos e imágenes, emplean tareas similares, pero en su lugar cuando se habla de materiales visuales, los estudiantes tienen que desarrollar modos adicionales de utilizar tales datos. 


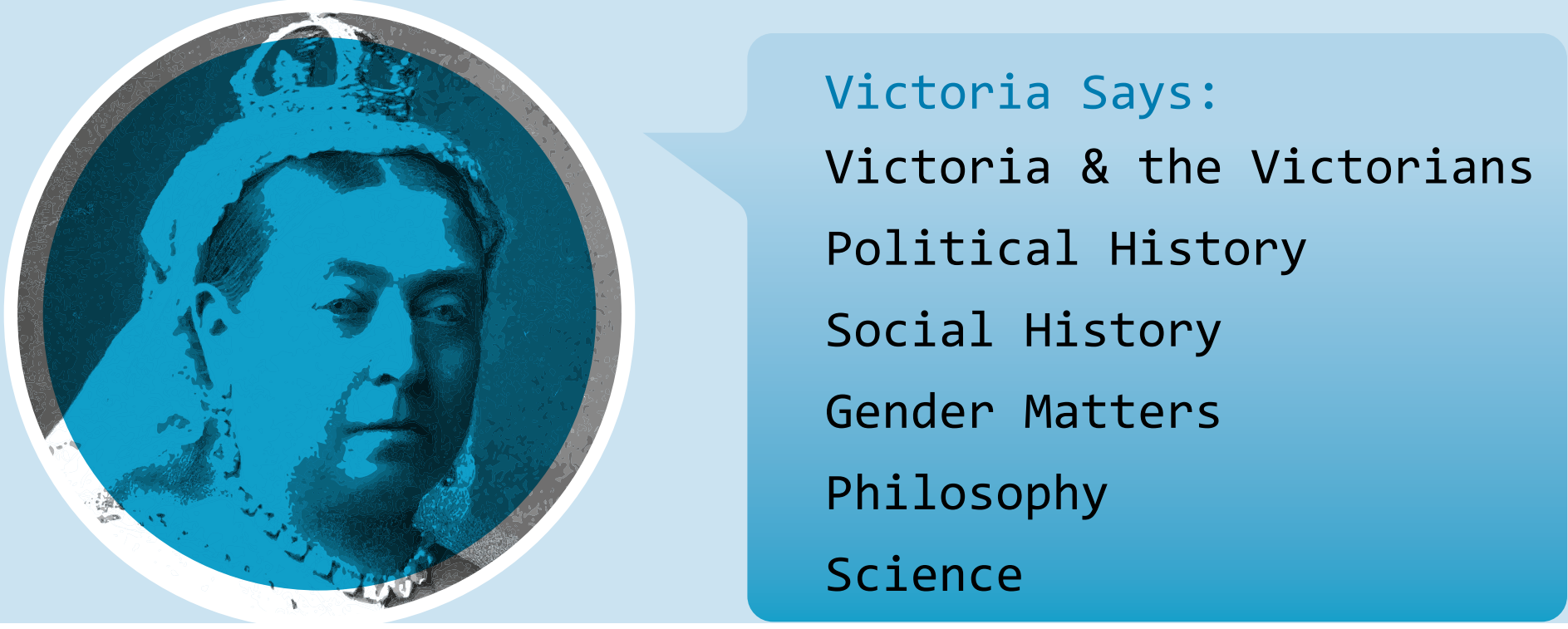

\section{The Assignment used for both the Wiki and The Victorian Web}

Here is the weekly assignment for the 2009 (Victorian Web) version of the student contributions:

"Weekly discussion questions. The course relies heavily on student-centered discussion generated by the weekly writing assignments. These reading and discussion questions have several required parts:

-Choose a substantial passage of 1-3 paragraphs or stanzas when discussing a literary text; choose a single work when discussing a painting, drawing, or example of decorative art; - Create a graceful and effective introduction to the material you chose that suggests why the reader should want to follow you as you examine it closely;

-Follow the quoted passage with at least one paragraph of commentary.

-Ask 4-5 questions, chiefly concerning matters of technique and comparison to other works, for which you do not have to have answers. As the semester progresses at least one question should involve a comparison of the poem or other text you discuss with one read in a previous week.

-Provide a title for your question set and include your expected graduating class.

These exercises, which provide the basis of class discussion, should generally be e-mailed to me no later than $6 \mathrm{pm}$ Sunday before we begin discussing the reading, though you can also occasionally send them in Monday or Tuesday. (You can skip a single set of questions during the semester, and we may not have one the final week of classes.) (courses/60.2009.html\#writing)."

This assignment, which I have described more briefly elsewhere (Landow 2006 286-91) and which I have used in both classes for beginning students and graduate seminars [note example of
URLs], has the following purposes or instructional goals:

To enable students to develop skills at choosing pertinent data that supports an argument or interpretation.

To enable students to develop skills at choosing data that will provide the basis for an interesting and educationally informative discussion with their classmates.

To enable students to make effective introductions to data, which in this class consists of passages of text from literary works. Such introductions should include the reason for quoting the text while convincing readers that the writer has a command of the information the text presents. (Other classes on painting, sculpture, and decorative arts in which data consists of both texts and images employ similar assignments, but instead when discussing visual materials, students have to develop additional modes of using such data.[note])

To enable students to develop skills at choosing data that provides an effective way to begin an essay (or to open a section within an essay divided into distinct parts with subtitles).

To enable students to develop techniques for moving effectively from such substantial passages of quoted text to the subsequent sections of their arguments.

To introduce students to an effective way of avoiding writer's block, the difficulty of beginning to write when encountering that intimidating blank writing surface, whether a sheet of paper or screen.

To enable students to develop skills at formulating questions based on their chosen data. Such questions, which for an audience substantiate the reason the author has chosen the passage in the first place, serve in class meetings as topics for discussion; in writing actual essays, such questions can provide the basis of subsequent sections of the argument. 
Las instrucciones para contribuir al curso Wiki, por el contrario, tenían direcciones más específicas y explicaciones de los objetivos de la tarea, incluyendo los siguientes:

"Dado que la mayoría de nosotros, novato o profesional, tiene dificultades para pasar de una idea o un argumento a una evidencia, o desde el texto de nuevo a un argumento, de vez en cuando debería tratar de crear una introducción interesante y eficaz en el pasaje elegido, que sugiera por qué el lector debe querer seguirlo cuando lo examina de cerca. Sugerencia: nunca introducir un pasaje con "[el autor] dice" o "afirma que".

"Formular una o varias preguntas (para las cuales no tienes que saber las respuestas) acerca de algo que no sea el sentido de la vida o alguna otra gran idea, es decir, una técnica, un tema de contexto, o ambos".

\section{Resultados}

Aunque las instrucciones anteriores para la contribución de la Wiki la hacían parecer más libre que las versiones anteriores de esta tarea, en la práctica los estudiantes siguieron exactamente la misma asignación.

\subsection{Uso de la Wiki por parte de los estudiantes}

A pesar de que en la primavera de 2010 los estudiantes no tuvieron dificultad en producir material en la Wiki, lo cual no requiere un gran dominio de idiomas, en general no la experimentaron o utilizaron como un hipertexto. Durante las primeras dos semanas algunos estudiantes no comprendieron la diferencia entre una contribución y anotar o comentar en

\subsection{Resultados inesperados}

Ambos grupos de estudiantes en 2009 y 2011 completaron un cuestionario de 22 puntos, donde la mayor parte de los temas (por ejemplo, evaluación estudiantil de los docentes, lectura breve o tiempo dedicado a textos individuales), no son relevantes para este estudio. Algunas de las preguntas pertinentes, sin embargo, produjeron resultados interesantes, contrarios a la intuición inicial. Mientras que el curso Wiki contenía preguntas y comentarios sólo de miembros de la clase del 2010, la Web Victoriana combinaba las contribuciones de los estudiantes del 2009 con un cuerpo del material más grande, como preguntas y ensayos extensos de miembros de otras clases, material de libros y artículos publicados.

Por lo tanto, se podría esperar que los usuarios de la Wiki pusieran más énfasis en los textos escritos por miembros de su propia clase, es decir, los estudiantes de la cohorte de 2009, ya que las contribuciones del 2010 se aislaron de los demás materiales del curso. De hecho, aproximadamente el 50\% de los estudiantes, en ambos años, leyó el trabajo de miembros de su clase cada semana, y el otro 50\% lo hizo una o dos veces durante el período académico. Del mismo modo (y esto es algo sorprendente), el las contribuciones de otros estudiantes. Muy pocos miembros de la clase hicieron anotaciones sobre el trabajo de los demás en la Wiki y casi ninguno de ellos agregó los enlaces, a pesar de las sugerencias de los docentes para hacerlo. Esencialmente, experimentaron la Wiki como un servidor de listas anticuado o lista de discusiones.

resultado en cada año, para quienes siguieron los enlaces en la Web Victoriana y leyeron el trabajo de los estudiantes en clases anteriores, también se dividió de la misma manera, 50\% lo hizo cada semana y el otro $50 \%$ sólo de vez en cuando.

También se suponía que los estudiantes cuyas asignaciones semanales aparecieron sólo en la Web Victoriana, seguirían más conexiones que las tareas que aparecieron en la Wiki independiente, sin embargo, no se presentaron diferencias significativas entre los dos grupos. En 2009 y 2010 los estudiantes entraron en la Web Victoriana básicamente de la misma manera: mientras que la mayoría de los alumnos de las dos clases se inició con el programa de estudios, entre el $25 \%$ y el $30 \%$ de ambos grupos se inició con la página Web y su exploración, sólo unos pocos fueron directamente a los autores individuales (por ejemplo, los temas individuales de la semana). Así, uno de los descubrimientos más importantes es que los estudiantes no transfirieron su aproximación más hipertextual de la utilización de la página Web a la Wiki, ni sus modos de usar la Wiki afectaron su acercamiento a la página Web más extensa. 
The instructions for contributing to the course Wiki, on the other hand, had somewhat more specific directions and explanations of the goals of the assignment, including the following:

"Since most of us, whether freshman or faculty, have difficulty moving from an idea or argument to our evidence, or from the text back to our argument, you should occasionally try to create a graceful and effecti-

\section{RESULTS}

Although the previous instructions for the wiki contribution made it seem more freeform than the earlier

\subsection{Student use of the wiki}

Although the Spring 2010 students had no difficulty inputting material on the wiki, which did not require knowledge of markup languages, in general they did not either experience or use it as a hypertext. During the first few weeks some students did not grasp the difference between a contribution and annotating or commenting on other student's contributions. Very

\subsection{Unexpected Results}

Students in both 2009 and 2011 completed a 22-item questionnaire, most of whose topics (e.g., student evaluation of the instructors' brief lectures or time devoted to individual texts) are not relevant this study. A few of the relevant questions, however, produced interesting, counter-intuitive results. Whereas the course wiki contained question-sets and commentary only by members of the 2010 class, the Victorian Web combined the student contributions from 2009 with a far-larger body of material, such as question sets and long essays by members of other classes and material from published books and articles. One might therefore have expected that users of the wiki would place far more emphasis on texts written by members of their own class than did the 2009 cohort since the 2010 contributions were isolated from the other course materials. In fact, approximately $50 \%$ of the students in both years read work by members of their class each week and another $50 \%$ did so only once or twice during the term. Similarly (and this result is perhaps surprising) the percen- ve introduction to the passage you chose that suggests why a reader should want to follow you as you examine it closely. Hint: never introduce a passage with "[an author] says" or "states."

"Ask a question or questions (for which you do not have to know the answer) about something other than the meaning of life or some other big idea — say, some technique, matter of context, or both." versions of this assignment, in practice students followed exactly the same assignment.

few members of the class ever made annotations to work by others on the wiki despite the instructors' suggestions to do so, and almost none of them ever added links, despite repeated encouragement to do so. Essentially, they experienced the wiki as an old-fashioned listserve or discussion list.

tages of those in each year who followed links in the Victorian $W e b$ and read work by students in previous classes also divided the same way - 50\% did so every week, and 50\% did so only rarely.

One might also have predicted that students whose weekly assignments appeared only in the Victorian Web would follow more links than those who assignments appeared in the separate wiki, but no significant difference appeared between the two groups. Students in 2009 and 2010 entered the Victorian Web in approximately the same way: whereas most students in both classes began with the syllabus, approximately $25 \%$ to $30 \%$ of both groups began with the homepage and explored, and only a few went straight to individual authors (i.e., topics of individual weeks). One the most important discoveries, therefore, was that students did not transfer their more hypertextual approach of using the website to the wiki, nor their modes of using the wiki affect their approach to the larger website. 


\subsection{Ventajas y desventajas para los docentes}

La utilización de la Wiki Victoriana en lugar de la Web Victoriana supuso un beneficio obvio para los docentes -ahorrándoles una enorme cantidad de tiempo y esfuerzo-, sin embargo, este resultado positivo se dio a un costo. La siguiente descripción del procedimiento empleado cada semana para integrar el trabajo de los estudiantes en la Web Victoriana, en las interacciones anteriores de la clase, hace evidente la diferencia en cuanto al refuerzo requerido para solventar los inconvenientes:

Cada semana los estudiantes enviaban por correo electrónico sus tareas semanales al docente, incorporándolas al cuerpo del correo (el método preferido) o como archivo adjunto de Word. Tal metodología hizo que el docente debiera corregir la escritura de los estudiantes, agregando sugerencias sobre el estilo y el contenido.

Durante las primeras dos semanas el docente presentó a los miembros de la clase algunas etiquetas HTML básicas, empezando por un párrafo; la siguiente semana añadió su etiqueta CSS para citas largas y, por último, esa etiqueta para la cursiva. De hecho, su trabajo apareció en el sitio con etiquetas CSS adicionales y más complejas, pero los cambios globales hicieron la conversación más fácil ${ }^{6}$. Frente a esto, el docente incorporó los documentos de los estudiantes en las plantillas preparadas, agregando vínculos entre el documento y otros textos escritos por los estudiantes de la clase actual y de las anteriores, así como el trabajo de otros académicos.

A las pocas horas de recibir las contribuciones de los estudiantes, el docente subía los documentos completos en HTML a los directorios adecuados utilizando victorianweb.org; también agregó versiones revisadas de los estudiantes y enlaces recomendados. Aunque esta forma de incorporar el trabajo de los estudiantes en un sitio Web accesible al público, podría parecer a primera vista especialmente dispendiosa, en la práctica no toma más tiempo que la clase convencional y la preparación de lecturas. Así, las sesiones de clase involucran principalmente discusiones dirigidas por los estudiantes, que utilizan sus cuestionarios, y se proyectan en una pantalla en la parte delantera del aula, intercaladas con una mini-charla ocasional del docente (5-10 minutos), que requiere de poca preparación adicional. Además, gracias a que las tareas asignadas son cortas y permiten a los estudiantes y al docente trabajar en la mejora de la escritura de los estudiantes a través de pequeñas tareas frecuentes, el tiempo y el esfuerzo empleados resultaron adecuados, porque fueron capaces de mejorar la escritura, ofrecer menos trabajo, y sin duda, menos trabajo desagradable que la evaluación de la escritura en grandes proyectos.

En comparación con el esfuerzo que involucra la preparación de trabajos de los estudiantes para la Web Victoriana, la Wiki del curso ofrece una clara ventaja para los docentes, pues elimina su trabajo y a los intermediarios o guardianes, así como la necesidad de hacer etiquetado HTML.

$\mathrm{Al}$ mismo tiempo, la Wiki presentó tres desventajas o efectos negativos, comparada con la utilización de un sitio Web más extenso. Primero, mientras la asignación de tareas de escritura semanales para los estudiantes en el sitio Web, hace que el curso sea más fácil pues permite que vean la relación de su trabajo y la contribución de sus compañeros con la gran cantidad de material existente, enfatizando así en el trabajo colaborativo y su relación con el aporte estudiantil hecho en años anteriores, la Wiki tiende a funcionar como un recurso independiente. Por otra parte, incluso en la Wiki, los estudiantes tendían a no moverse entre las diferentes lecturas separadas por semanas, concentrándose únicamente en las lecturas que tenían a la mano. Ambos efectos socavan el paradigma educativo que se encuentra en el corazón de la propuesta del profesor de la clase.

Por último, el uso de la Wiki tiene una desventaja que no es especialmente importante para este sitio Web en particular, pero que sí podría ser importante para otros: la Wiki exige mucho menos trabajo de los estudiantes, comparado con aquel que se requiere para la inclusión en un sitio Web del curso; esto significa una baja calidad de escritura de ambos y contribuciones menos detalladas. Un lector anónimo del presente artículo plantearía la siguiente pregunta: "Teniendo en cuenta que el trabajo de alta calidad de los estudiantes fue extraído de la Wiki, reformateado, y colocado en la Web Victoriana, ¿podría este procedimiento crear/reforzar la impresión de que la Wiki funciona como un archivo bloc de notas separado, desalentando así el trabajo de alta ca-

6 Etiquetas realmente utilizadas en el sitio incluyen $<\mathrm{p}$ class $=$ "one" $>$ de primera línea, alineado a la izquierda, de un documento o subsección de un documento, $<\mathrm{p}$ class="lq" $>$ de sangría, determinado para citas largas, $<$ p class="poetry" $>$ para citar poesía, $<$ p class="ques" $>$ para preguntas de discusión, y $<$ p class="bibl" $>$ para párrafos con sangrías utilizadas en bibliografías. Además, se emplearon diferentes etiquetas, como $<$ span class $=$ "book" $></$ span $>$ y $<$ span class $=$ "ship" $></$ span>, para diferentes clases de elementos que aparecen en cursiva. Cada semestre, algunos estudiantes particularmente hábiles utilizaban el comando "Ver Fuente": en sus navegadores Web, vieron el formato real y enviaron su trabajo completamente formateado]. 


\subsection{Advantages and Disadvantages for Instructors}

Using the Victorian wiki rather than the Victorian Web had one immediately obvious benefit for instructors - it saved them an enormous amount of time and effort - but this positive result came at a cost. The following description of the procedure employed each week for placing student work on the Victorian Web in the previous iterations for the class makes the difference in effort required clear:

Each week students e-mailed their weekly assignments to the instructor, placing them in the body of the e-mail (the preferred method) or as Word attachments.

The instructor then corrected student writing, adding suggestions about style and content.

During the first week or two the instructor introduced members of the class to a few basic HTML tags, beginning with that for a paragraph; the next week he added his CSS tag for long quotations, and finally that for italics. Their work in fact appeared on the site with additional, more complex CSS tags; but global changes made the conversion easy. [Tags actually used on the site include $<\mathrm{p}$ class $=$ "one" $>$ for first line, flush left, of a document or subsection of a document, $<$ class $=$ "l $q$ " $>$ for indented, setoff long quotations, $<$ p class="poetry" $>$ for quoting poetry, $<p$ class="ques" $>$ for discussion questions, and $<\mathrm{p}$ class="bibl" $>$ for paragraphs with hanging indents uses in bibliographies. In addition different tags, such as $<$ span class ="book" $></$ span $>$ and $<$ span class $=$ "ship" $></$ span $>$ were employed for different classes of items that appear in italics.

Every semester a few particularly astute students used the "View Source": command in their web browsers, saw the actual formatting, and sent in their work fully formatted.]

The instructor placed the student documents in prepared templates, adding links between the document and others written by students in the current class and earlier ones as well as work by established scholars.

Within a few hours of his receiving student contributions, the instructor uploaded the completed html documents to appropriate directories in victorianweb.org.

The instructor also added students' revised versions as well as links they suggested.

Although this way of incorporating student work into a publicly accessible website might at first appear particularly burdensome, in practice it takes no more time than usual class and lecture preparations. And since the class sessions chiefly involve student-led discussions employing their question sets, which are projected on a screen at the front of the classroom, interspersed with an occasional brief (5-10 minute) mini-lecture by the instructor, the instructor has little additional preparation. Furthermore, since the brief assignments permit students and instructor to work on improving student writing in frequent, small assignments, again the time and effort expended proved well spent because grading improved writing provides less work, and certainly less unpleasant work, than grading poor writing on major projects.

Compared to the effort involved in preparing student work for the Victorian Web, the course wiki has the clear advantage for instructors both of removing them as intermediaries or gatekeepers and also removing the need to do html tagging.

At the same time, the Wiki had three major disadvantages or negative effects when compared to using the more time-consuming website. First, whereas placing student weekly writing assignments within the course website makes it easier for students to see the relation of their own and fellow students contributions to the large body of existing material, thus emphasizing both collaborative work and current students' relation to work done by those from years before, the wiki tended to function as a stand-alone resource. Moreover, even on the wiki students tended not to move among the various readings from separate weeks, concentrating instead solely on the reading at hand. Both effects essentially undercut the educational paradigm that lies at the heart of the instructor's conception of the class.

Finally, using a wiki has one particular disadvantage not particularly relevant to the particular website used for the class but which might prove important to others: the wiki provided much less student work suitable for inclusion in a course-related site less suitable largely because of both poorer quality writing and less detailed contributions. An anonymous reader of this paper posed the following astute question: "Given that any high(er) quality student work was extracted from the wiki, reformatted, and placed in the Victorian Web - could such procedure have created/strengthened an impression of the Wiki as a separate "scratchpad," thereby not encouraging higher-quality work?" No, the instructors placed the same emphasis on ways to improve style and handling of evidence as in earlier iterations of the class.

For instructors wanting to boot-strap an educational website and thereby create a community memory for a particular course or subject, the wiki would not work very well. (Landow did, however, take a few student question sets per week, format them, and place them in the Victorian Web as a way of emphasizing their high quality. Students were encouraged to nominate work by other class members for this honor.) 
lidad?” No, los docentes dieron el mismo énfasis a la forma de mejorar el estilo y al tratamiento de las iteraciones anteriores de la clase.

Para los docentes que quieran desarrollar un sitio Web educativo y de ese modo crear una memoria común para un curso o tema en particular, la Wiki no funciona muy bien. (Sin embargo, se tomaron algunos cuestionarios de los estudiantes por semana, fueron formateados e integrados en la Web Victoriana, como una forma de destacar su gran calidad. Los estudiantes fueron estimulados para que nominaran el trabajo de otros miembros del grupo y que fueran resaltados en dicha Web).

\subsection{Ventajas y desventajas para los estudiantes}

La Wiki también tenía evidentes ventajas y desventajas para los estudiantes. La desventaja más significativa es que no permitió una mejora importante de su escritura, comparándola con el desarrollo de los estudiantes que en las clases anteriores presentaron sus cuestionarios y comentarios al docente. Dos factores en relación con la diferencia entre la Wiki y la Web Victoriana parecen explicar este fenómeno: primero, la eliminación de la función de control y curaduría del docente y sus comentarios, en el proceso de pre-publicación, afecta un componente educativo importante, pues los cuestionarios de los estudiantes no van primero a los docentes, quienes actuarían como curadores, lo cual afecta el proceso de retroalimentación casi inmediata, que consiste en correcciones y sugerencias ${ }^{7}$.

Hay que destacar, sin embargo, que a pesar de que el docente no fue obligatoriamente el curador: a) Ocasionalmente adjuntaba comentarios sobre el estilo y el contenido de las contribuciones individuales de los estudiantes en la Wiki; b) Cada vez con más frecuencia envió comentarios por correo electrónico a los estudiantes, ya sea cuando se mostraron especialmente críticos, o para responder observaciones frecuentes en las sesiones de clase; y c) Invitó a los estudiantes a enviar por correo electrónico sus contribuciones a la Wiki o a él si querían una retroalimentación privada. En otras palabras, todos los componentes incluidos en el anterior enfoque de la Web Victoriana de la tarea, estaban presentes pero ya no eran obligatorios.

Un segundo factor consiste en el hecho de que asumir las funciones de la Wiki como un sitio cerrado, privado, aísla a los

escritores frente a posibles críticas de los lectores fuera de la clase e incluso fuera de la universidad. Aunque es probable que su trabajo reciba gran cantidad de lecturas, un menor nivel de crítica realizada por personas ajenas no parece ser tan importante como la noción del escritor acerca de poseer una audiencia, algo que los maestros de la escritura expositiva siempre tratan de inculcar, pero que rara vez pueden hacer. Una cosa es que el docente diga a los estudiantes que tienen que escribir con una audiencia en mente, y otra, decir que su audiencia está compuesta de lectores no presentes en el curso y que, por lo tanto, necesitan una explicación clara de los argumentos que un miembro de la clase (podría) entender, pero que personas fuera de su clase o extraños podrían no hacerlo. Esto es, los estudiantes deben escribir pensando que la audiencia pueda leer lo que escriben y no sólo los amigos y los padres.

Otra diferencia, aunque probablemente menos importante, es que los estudiantes no aprenden HTML, habilidad que en un futuro próximo puede resultar innecesaria. Por último vale la pena aclarar que los estudiantes de hecho no aplicaron hábitos y actitudes relacionados con el uso del hipertexto a la Wiki. Este resultado parecería ofrecer un ejemplo más del enfoque de "coche sin caballos", por ahora común a los nuevos medios de comunicación, en el que en lugar de percibir las capacidades de un nuevo ambiente de lectura y escritura, los estudiantes tienden a seguir la página o paradigma de la cultura impresa (Landow 2006 314-20; Landow 2009).

\section{Conclusiones}

Aunque la Wiki tuvo generalmente menos éxito que la Web Victoriana en el cumplimiento de las metas del docente, resulta, sin embargo, prometedora, especialmente para cursos extensos que dejan poco espacio para la discusión en clase y tienen demasiados estudiantes para que un solo docente emplee el método clásico de preguntas semanales.

7 Para una explicación detallada de los motivos de esta evaluación, se recomienda revisar el Apéndice 6. 


\subsection{Advantages and Disadvantages for Students}

The Wiki also had obvious advantages and disadvantages for students, the most important disadvantage being that their writing did not improve as much as had that by students in previous classes who submitted their question sets and comments to the instructor. Two factors, both related to the difference between the wiki and the Victorian $W e b$ would seem to be the cause. First and most obvious, removing the instructor's gatekeeping function and related pre-publication comments also removed an important instructional component. Because student question sets do not first go to the instructors, who thus serve as gatekeepers, they do not receive rapid, often near-immediate feedback, consisting of corrections and suggestions. (For a detailed explanation of the grounds for this evaluation, see Appendix 6.)

One must emphasize, however, that although the instructor no longer served as mandatory gatekeeper, he (a) occasionally attached comments about both style and content to individual student contributions on the wiki, (b) more frequently he e-mailed comments to individual students, either when they were particularly critical or repeated remarks made frequently in class sessions; and (c) invited students to e-mail their wiki contributions to him if they wanted private feedback. In other words, all the components of the older the Victorian Web approach to the assignment were present, but they were no longer mandatory. A second factor involves the fact that the wiki functions

\section{Conclusions}

Although the wiki proved generally less successful than did the Victorian Web in fulfilling the instructor's goals, it nonetheless has promise, specially for large lecture courses

\section{Acknowledgements}

Thanks to Ademar Aguiar, Mark Bernstein, Stewart Mader, and Nathan Matias of the WikiSym2008 program committee and Mark LaPorte of the TikiWiki group for encouraging me to undertake this project. I'd also like to thank the Brown University Wiki ser- as a closed, private site, and thus insulates writers from exposure to potential criticism from readers outside the class and even outside the university. Whether their work is in fact ever likely to receive such readings, much less such criticism, by outsiders does not seem to be as important as the writer's awareness of an audience - something which teachers of expository writing always try to instill but rarely can do. It is one thing for an instructor to tell students that they must write with an audience in mind, with one, moreover, composed of readers not present in their course and who therefore need clear explanations of arguments and allusions members of the class (might) understand; it is very different when they know that people outside the present class can read what they write - say, not only friends and parents but also strangers

Another, though probably unimportant difference involves the fact that students do not learn html, which of course may be a skill that in the near future becomes quite unnecessary. Finally, as the preceding discussion makes clear, the students did not in fact apply habits and attitudes associated with using hypertext to their use of the wiki. This result would seem to provide yet another example of the by-now common horseless-carriage approach to new media in which, rather than perceiving the capacities of a new reading and writing environment, students tend to follow the page or print culture paradigm (Landow 2006 314-20; Landow 2009). which leave little room for class discussion and have too many students for a single instructor to employ the weekly question-set method.

vice, a part of the university's Instructional Technology Group (ITG), for setting up the Victorian Wiki and my teaching assistant, Katherine M. Miller, for creating weekly organization. Finally, I'd like to thank my students in both iterations of English 0600J. 


\section{Agradecimientos}

Gracias a Ademar Aguiar, Mark Bernstein, Stewart Mader y Nathan Matias, del comité del programa WikiSym2008, y a Mark LaPorte, del grupo TikiWiki, por animarme a realizar este proyecto. También al servicio de Wiki de la Universidad de Brown, y a una parte del Grupo de Tecnología Educativa de la Universidad (ITG), por la creación de la Wiki Victoriana; tampoco puedo olvidar los aportes de mi asistente, Katherine M. Miller, y su contribución con la creación de la organización semanal y, por último, quisiera dar las gracias a mis alumnos en los dos cursos de 0600J Inglés.

\section{Referencias}

Bernstein, Mark. (1991). "Storyspace and the process of writing”. En E. Berk y J.Devlin, (Eds.). Hypertext/Hypermedia Handbook. New York: McGraw-Hill.

Bernstein, Mark. (2002). “Storyspace 1". Proceedings of the 13th Hypertext Conference; Hypertext. New York: ACM, 172-181.

Bernard, J. H., Kahn, P., Riley, V. A., Coombs, J. H., y Meyrowitz, N. K. (1992). "IRIS Hypermedia Services". Communications of the ACM, $35,36-51$.

Kahn, P. D. (1992). Intermedia: A Retrospective. [Video]. New York: Association for Computing Machinery.

Landow, G. P. (1991). "Connected Images: Hypermedia and the Future of Art Historical Studies". En Scholarship and Technology in the Humanities. London: British Library Research/Bowker Saur, 77-94.

Landow, G. P. (2006). Hypertext 3.0: New Media and Critical Theory in an Era of Globalization. Baltimore: Johns Hopkins University Press.

Landow, G. P. (2007). “Comparative Literature from Text to Hypertext, o What Do Electronic Media Have to Offer the Discipline?” En Literatures in the Digital Era: Theory and Praxs. Cambridge: Cambridge Scholars Publishing, 23-40.

Landow, G. P. (2009). “Creative nonfiction in electronic media: new wine in new bottles?” Neohelicon. Budapest, 36, 439-50.

Landow, G., y Kahn, P. (1992). “Where's The Hypertext? The Dickens Web as a System- Independent Hypertext”. ECHT'92. New York: ACM.

Landow, G. P., Launhardt, J., y Kahn, P. D. (1990). The Dickens Web. 1990. Environment: Intermedia 3.5. Providence, R.I.: Institute for Research in Information and Scholarship.

Landow, G. P., y Miller, K. M. (2010). “How much do students have to know about the media with which they learn?” Pedagogika.it. Italy, 14, 26-36.

Lanestedt, J., y Landow, G. P. (Eds). (1992). The “In Memoriam” Web. Environment: Storyspace. Watertown: Eastgate Systems.

Yankelovich, N., Meyrowitz, N., y Drucker, S. (1988). "Intermedia: The Concept and the Construction of a Seamless Information Environment". IEEE Computer 21, 81-96. 


\section{References}

Bernstein, Mark. 1991. "Storyspace and the process of writing," in E. Berk and J.Devlin, eds., Hypertext/Hypermedia Handbook. New York: McGraw-Hill.

Bernstein, Mark. 2002. "Storyspace 1.” Proceedings of the 13th Hypertext Conference; Hypertext, Ed. Ken Anderson, Stuart Moulthrop and Jamie Blustein. ACM, New York. 172-181.

Haan, Bernard J., Paul Kahn, Victor A. Riley, James H. Coombs, and Norman K. Meyrowitz. 1992. "IRIS Hypermedia Services." Communications of the ACM 35: 36-51.

Kahn, Paul D. 1992 Intermedia: A Retrospective. 53-minute video. New York: Association for Computing Machinery, 1992.

Landow, George P. 1991. “Connected Images: Hypermedia and the Future of Art Historical Studies.” In Scholarship and Technology in the Humanities. Ed. May Katzen. London: British Library Research/Bowker Saur. 77-94.

Landow, George P. 2006. Hypertext 3.0: New Media and Critical Theory in an Era of Globalization. Johns Hopkins University Press. Baltimore.

Landow, George P. 2007. "Comparative Literature from Text to Hypertext, or What Do Electronic Media Have to Offer the Discipline?” in Literatures in the Digital Era: Theory and Praxs. Ed. Amelia Sanz and Dolores Romero. Cambridge Scholars Publishing. Cambridge (UK). 23-40.

Landow, George P. 2009. “Creative nonfiction in electronic media: new wine in new bottles?” Neohelicon. Budapest. 36: 439-50.

Landow, George, and Paul Kahn. "Where's The Hypertext? The Dickens Web as a System- Independent Hypertext.” ECHT’92. New York: ACM, 1992.

Landow, George P. . Julie Launhardt and Paul D. Kahn., The Dickens Web. 1990. Environment: Intermedia 3.5. Providence, R.I.: Institute for Research in Information and Scholarship, 1990.

Landow, George P. and Katherine M. Miller. 2010. "How much do students have to know about the media with which they learn?” Pedagogika.it. Italy. 14 (2010): 26-36.

Lanestedt, Jon and George P. Landow, eds. 1992. The “In Memoriam” Web. Environment: Storyspace. Watertown: Eastgate Systems.

Yankelovich, Nicole, Norman Meyrowitz, and Stephen Drucker. 1988. "Intermedia: The Concept and the Construction of a Seamless Information Environment.” IEEE Computer 21 (1988): 81-96. 


\section{Apéndice. La Web Victoriana, 1987-2010}

\section{La Web victoriana y el Contexto32}

La Web Victoriana es la traducción de WWW de la Universidad de Brown "Contexto 61", útil como un recurso para los cursos de literatura victoriana. Estos materiales se derivan en última instancia de Contexto 32, la Web Intermedia que proporciona información contextual para Inglés 32, "Estudio de la literatura Inglesa desde 1700 hasta el presente". Contexto 32 se inició en la primavera de 1987 como parte del Instituto de la Universidad de Brown para la Investigación en Información y Becas (IRIS) Intermedia (Yankelovitch, et al., 1988; Hahn, et al., 1992; Kahn, 1993), que es financiada por IBM, Apple Computers, la Annenberg/CPB Project y otras fuentes. George P. Landow diseñó y editó todos los materiales para el antecesor del sitio actual, hizo muchos de los enlaces y fue responsable de la mayor parte de los materiales de los autores individuales y obras, así como de lo relativo a la tipología bíblica.
Escribió varias lexías en toda la Web y seleccionó tanto la crítica externa citada, como la mayoría de las imágenes visuales. Bajo su dirección, David Cody escribió muchos de las materiales generales y optó por muchas de las imágenes digitalizadas originales, mientras que Glenn Everett escribió algunos de los materiales básicos de poetas románticos y victorianos, incluyendo líneas de tiempo; por su parte, Kathryn Stockton creó algunos documentos sobre el feminismo y la teoría literaria.

Anthony S. Wohl, profesor de Historia en la Universidad de Vassar, generosamente aportó gran parte del material sobre la salud pública victoriana, cuestiones de raza y de clase, y los prejuicios anti-católicos en la Inglaterra victoriana. Fue el primer colaborador no-Brown desde hace siglos. Su trabajo se basa tanto en sus publicaciones como en escritos inéditos.

\section{Transferencia de los materiales Inter Media a Eastgate Systems Storyspace}

En 1992, Robert Arellano, de la Universidad Brown '90, transfirió la mayor parte de los documentos del sistema de Intermedia (que dejó de funcionar en 1992), al Eastgate Sistems Storyspace (Bernstein, 1991 y 2001) y los volvió a enlazar.

La Web Victoriana también se basa en otras webs de hipertexto desarrolladas bajo la dirección de Landow. En particular, la mayoría de los materiales de Dickens provienen originalmente de la Web Intermedia de Dickens, que Julie Launhardt y Paul Kahn ensamblaron (Landow, et al., 1990). Este trabajo ganó el 1990EDUCOM/NCRIPTAL, al mejor software en Humanidades, y ha sido publicado en Storyspace por Eastgate Systems, de manera similar, la mayoría de los materiales de Tennyson se han tomado de la In Memoriam Web (Lanestedt, et al., 1992.), también publicado por Eastgate Systems.

En 1993, David Stevenson'96 reorganizó la riqueza de materiales en la forma en que aproximadamente se encuentran ahora, especialmente muchos de los pertenecientes a los autores importados; también escribió algunos materiales biográficos, construyó y vinculó una visión general de todas las obras (mapas de sitio), desarrolló diversas descripciones contextuales y fue el responsable de la importación de una cantidad importante de materiales de la Web. En un mes de trabajo durante el verano de 1993 en IRIS, la red creció de uno a tres megabytes, ganando más de mil enlaces, y adquirió la estructura y la forma que se ve en este momento.

\section{Transferencia del Storyspace Web en HTML}

En 1994, Marc Zbyszynski’95, comenzó el laborioso proceso de volver a crear manualmente en HTML todos los menús de vínculos que Storyspace genera automáticamente. En mayo y junio de 1995, Landow creó los iconos, realizó el diseño y el uso de Storyspace 1.3w8, y Robert C. Mejor Web Weaver HTML 2.5., creó la versión HTML de la Web. Desde entonces, entre 2000 y 2002, Landow ha utilizado principalmente BBedit cuando se trabaja en Macs, y Homesite de Allaire cuando se trabaja en un entorno Windows.

\section{4. $\quad$ El programa de académicos de la Universidad Nacional de Singapur (USP)}

George P. Landow, como Decano fundador del Programa de la Universidad Nacional de Singapur (USP), patrocinó dos servidores de la Web Victoriana (uno en EE.UU. y otro en Singapur) 2001-2008. Entre Enero de 2001 y Diciembre de 2001, la USP también financió dos asociados principales de investigación, Dr. Marjorie Bloy y el Dr. John van 


\section{Appendix. The victorian Web, 1987-2010}

\section{The Victorian Web and Context32}

The Victorian Web is the WWW translation of Brown University's Context 61, which served as a resource for courses in Victorian literature. These materials ultimately derive from Context 32, the Intermedia web that provided contextual information for English 32, "Survey of English literature from 1700 to the Present." Context 32 was begun in Spring 1987 as part of Brown University's Institute for Research in Information and Scholarship (IRIS) Intermedia project (Yankelovitch et al. 1988, Hahn et al. 1992, Kahn 1993), which IBM, Apple Computers, the Annenberg/CPB Project, and other sources funded.

For this predecessor of the current site, George P. Landow designed and edited all the materials, made many of the links, and was responsible for most of the materials on the individual

\section{Transferring the Intermedia Materials to}

In 1992 Robert Arellano, Brown University '90 transferred most of the documents from the Intermedia system (which ceased operating in 1992) into Eastgate Systems Storyspace (Bernstein 1991 and 2001) and relinked them.

The Victorian Web also draws upon several other hypertext webs developed under Landow's direction. In particular, most of the Dickens materials come originally from the Intermedia Dickens Web, which Julie Launhardt, Paul Kahn, and he assembled (Landow et al, 1990). (It won the 1990 EDUCOM/NCRIPTAL award for best software in the humanities and has been published in Storyspace by Eastgate Systems); similarly, most of the Tennyson authors and works as well as those on Biblical typology. He wrote multiple lexias throughout the web and selected both the external criticism cited and most of the visual images. Under his direction David Cody wrote many of the general materials and chose many of the original digitized images, and Glenn Everett wrote some of the basic materials on Romantic and Victorian poets including timelines. The following year Kathryn Stockton created some documents on feminism and literary theory.

Anthony S. Wohl, Professor of History at Vassar College, generously contributed much of the material on Victorian public health, race and class issues, and anti-Catholic prejudice in Victorian England. He was the first non-Brown contributor; there have since been hundreds. His work draws upon both his published and unpublished writings.

\section{Eastgate Systems Storyspace}

materials are taken from the In Memoriam Web (Lanestedt et al., 1992), also published by Eastgate Systems).

In 1993 David Stevenson ' 96 rearranged this wealth of materials approximately into the form in which you now encounter them. He reorganized many of the materials on authors, imported and wrote some biographical materials, built and linked all works' overviews (sitemaps), and developed several of the contextual overviews. He was responsible for importing a significant amount of the web's materials. In one month's work over the summer of 1993 at IRIS, the web grew from one to three megabytes, gained over a thousand links, and acquired the structure and form that you see it in now.

\section{Transferring the Storyspace Web into HTML}

In 1994 Marc Zbyszynski'95, began the laborious process of manually recreating in HTML all the link menus that Storyspace automatically generates on the fly. In May and June 1995 Landow then created the icons, designed the layout, and using Storyspace 1.3w8 and Robert C. Best's HTML Web Weaver 2.5. created the HTML version of the Web. Since then Landow has chiefly used BBedit when working on Macs and Allaire's Homesite when working in a Windows environment between 2000 and 2002.

\section{The University Scholars Pro-gramme (USP) at the National University of Singapore}

The University Scholars Programme (USP) at the National University of Singapore, of which GPL was the founding dean, sponsored the Victorian Web's two servers (one in the USA and the other in Singapore) 2001-2008. Between January 2001 and December 2001 the USP also funded two senior research fellows, Dr. Marjorie Bloy and Dr. John van Whye, and a half dozen stu- dent assistants, who worked on The Victorian Web Books section and other major projects, including the site's materials on science, technology, and political and social history. In addition Dr. Tamara Silvia Wagner, a NUS-funded research fellow who worked primarily on the sister Postcolonial Literature and Culture Web, provided many valuable contributions. 


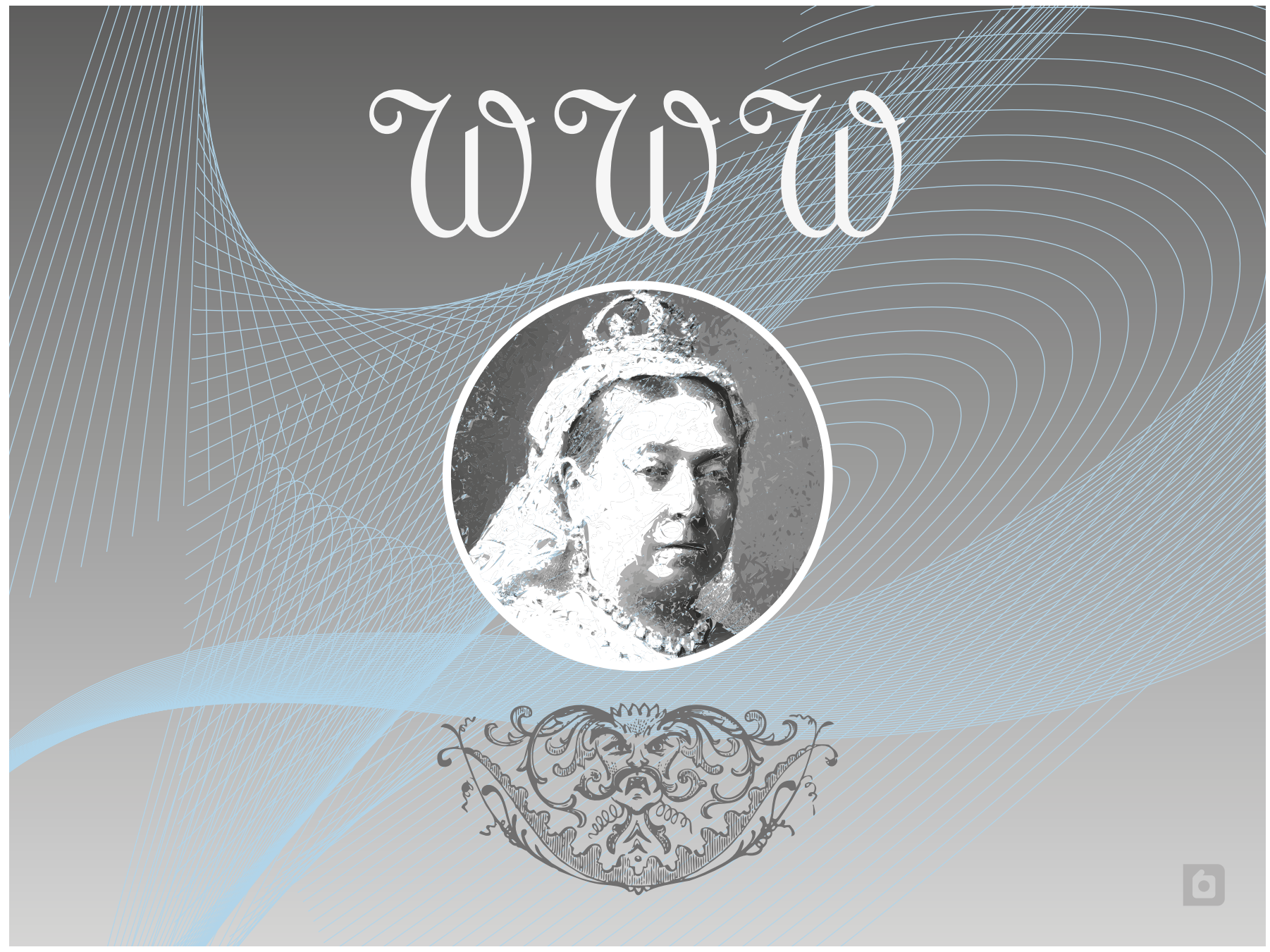

Whye, además de media docena de estudiantes asistentes que trabajaron en la sección de Libros Victorian Web y en otros grandes proyectos, incluyendo los materiales del sitio en ciencia, tecnología e historia política y social. Además del Dr. Tamara Silvia Wagner, investigador -NUS- quien trabajó principalmente en la Red hermana Postcolonial de Literatura y Cultura Web, proporcionando múltiples y valiosas contribuciones.

\section{Editores contribuyentes a la Web Victoriana para Canadá, el Reino Unido y Polonia}

Philip V. Allingham, ahora Profesor Asociado en la Universidad de Lakehead, Thunder Bay, Ontario, quien pasó diciembre de 2001 NUS como profesor investigador, se ha desempeñado como editor colaborador de la Web Victoriana desde el 2000. A partir de 1999, ha contribuido con aproximadamente 1.000 documentos sobre Ainsworth, Boucicault, Bulwer-Lytton, Collins, Dickens, Du Maurier, Hardy, Reade, Scott, Stevenson, y con más de una docena de ilustradores de libros ingleses. La Dr. Jacqueline Banerjee, quien se convirtió en editora del Reino Unido en 2005, 


\section{The Victorian Web's Contributing Editors for Canada, the U. K, and Poland}

Philip V. Allingham, now-Associate Professor at Lakehead University, Thunder Bay, Ontario, who spent December 2001 at NUS as Senior Fellow, has served as Contributing Editor to the Victorian Web since 2000. Since 1999, Allingham has contributed approximately 1000 documents on Ainsworth, Boucicault, Bulwer-Lytton, Collins, Dickens, Du Maurier, Hardy, Reade, Scott, Stevenson, and more than a dozen British book illustrators. Dr. Jacqueline Banerjee, who became our UK con-

\section{French and Spanish versions of the site}

In October 2009 Professor Asuncion López-Varela Azcarte of the Facultad de Filologia de Universidad Complutense de Madrid began to coordinate partial Spanish and French translation of the site that will be part of a three-year project entitled "Studies on Intermediality as Intercultural Mediation." This project is supported by grants from her university and from Madrid (Comunidad de Madrid CCG08UCM/HUM-3851) and the Ministry of Science and Innovation (Mi-

\section{Goals of the Course}

English 0600J has three main goals: helping students (a) become familiar with major works of British Victorian literature, 1830-1900; (b) develop interpretative skills; and (c) write effectively. Only the second and third of these are relevant to the technology discussed above. I have evaluated the relative effectiveness of the Victorian wiki and the Victorian Web in relation to improving students' the abilities to make sophisticated, multicausal explanations of complex texts. Basic interpretative skills here include distinguishing among an individual text's subject, themes, and contexts. For example, in Tennyson's In Memoriam the subjects include death, extinction of species, religious belief, and the role of poetry in the contemporary world; themes include the idea that God permits death and extinction of species only because divinely inspired evolution will create higher beings. Contexts here include contemporary geology, paleontology, typological biblical interpretation, contemporary poetic theory, and the poet's autobiography. Students in all courses consistently have most difficulty connecting texts to one or more contexts, and students using the wiki - even when the assignment required introducing matters of context — did a poorer job that classes who question sets appeared in the Victorian Web.

The writing skills that both iterations of the course consistently emphasized take the form of clear, definable techni- tributing editor in 2005 , has contributed an several thousand documents and images, many of which concern sculpture and architecture. She has also written numerous literary essays and book reviews of recent scholarship. Our most recent foreign contributing editor is Andrzej Diniejko, Senior Lecturer in English Literature and Culture at Warsaw University, who has contributed essays and reviews chiefly on the Victorian novel and its politic-economic contexts.

nisterio de Ciencia e Innovación MICINN FFI2008-05388/FISO). After each lexia (or separate document) is translated, two readers will vet it, after which it will appear in the non-English versions of the Victorian Web. Thus far, López-Varela and a team of five dozen translators have produced approximately 3,100 documents, which Landow has formatted. In August 2010 Landow began a French translation of the site, which now has about 1000 documents.

ques: (1) replacing weak passive writing produced by excessive uses of passives and forms of the verb "to be" by instead using active verbs that designate precise causal, temporal, or other relationships, (2) as part of this emphasis upon precise statements, having student writing avoid common misuses of words (such as using "while," a temporal adverb, when the writer means "whereas or although," or using "through," an adverb that convey movements through physical spaces when the writer means "by means of" or "with." When students acquire these and similar means of more precise writing, the course provides them with means of varying sentence structure beyond that used by skillful intermediate writers (noun + verb + object AND verb + object) to produce both more precise statements of causal, temporal, and subordinate relationships and interesting and thus more effective communication, as, for example, changing "The engineer wanted to create a lighter airframe and [he] employed new composites" to "The engineer, WHO wanted to create a lighter airframe, employed new composites" or "When the engineer wanted to create a lighter airframe, he employed new composites." Both instructors observed that, although emphasized frequently in class discussion, writing did not improve as expected on the wiki. 
ha contribuido con varios miles de documentos e imágenes, muchas de ellas sobre escultura y arquitectura; también ha escrito numerosos ensayos literarios y reseñas de libros de estudios recientes. La editora extranjera más reciente es An-

6. Versiones en francés y español del sitio En octubre de 2009, la profesora Asunción López-Varela Azcarte, de la Facultad de Filología de la Universidad Complutense de Madrid, comenzó a coordinar la traducción parcial española y francesa del sitio, tarea que sería parte de un proyecto de tres años titulado: "Estudios sobre Intermedialidad como Mediación Intercultural", y que fue apoyado por becas de la universidad de Madrid (Comunidad de Madrid CCG08-UCM/HUM-3851) y por el Ministerio de Ciencia e Innovación (Ministerio de Ciencia e Innovación

\section{Objetivos del curso}

Inglés 0600J, tiene tres objetivos principales: ayudar a los estudiantes a a) Familiarizarse con las principales obras de la literatura victoriana británica, 1830-1900; b) Desarrollar habilidades de interpretación, y c) Escribir de manera efectiva. Sólo la segunda y la tercera de ellas son relevantes para la tecnología expuesta anteriormente. Se ha evaluado la eficacia relativa de la Wiki Victoriana y la Web Victoriana en relación con la mejora de las habilidades de los estudiantes para realizar explicaciones sofisticadas, multicausales, de textos complejos. Las habilidades básicas de interpretación son objeto aquí de distinción entre un texto individual, temas y contextos. Por ejemplo, en In Memoriam, de Tennyson, los temas incluyen la muerte, la extinción de especies, las creencias religiosas y el papel de la poesía en el mundo contemporáneo; a la vez incluyen la idea de que Dios permite la muerte y la extinción de las especies sólo porque la evolución de inspiración divina creará seres superiores. Algunos contextos incluyen la geología moderna, la paleontología, la interpretación bíblica tipológica, la teoría poética contemporánea y la autobiografía del poeta. Los estudiantes de todos los cursos tienen dificultades más consistentes para conectar los textos de uno o más contextos, y los estudiantes que usan la Wiki -incluso cuando la tarea requiere de la introducción de temas contextuales-, han hecho un trabajo más pobre que aquellos que establecen el conjunto de preguntas en la Web victoriana.

Las habilidades escritas de ambas iteraciones del curso mencionado, toman la forma de técnicas que se pueden drzej Diniejko, profesor titular de Literatura y Cultura de Inglés en la Universidad de Varsovia, quien ha contribuido con ensayos y reseñas, principalmente sobre la novela victoriana y sus contextos político-económicos.

del MICINN FFI2008-05388/FISO). Después de que cada lexia (o documento separado) es traducida, dos lectores se encargaban de su revisión, luego de esto aparecia en las versiones no inglesas de la Web victoriana. Hasta el momento, López-Varela y un equipo de cinco docenas de traductores, han producido unos 3.100 documentos que Landow ha formateado. En agosto de 2010, el propio Landow comenzó una traducción francesa del sitio, que ahora cuenta con unos 1.000 documentos.

definir claramente: 1) La sustitución de la escritura débil, pasiva, producida por el uso excesivo de los verbos pasivos y las formas del verbo "ser", para en su lugar utilizar verbos activos que designan precisión causal, temporal, u otras relaciones; 2) Como parte del énfasis en las declaraciones precisas, se hace que los estudiantes escriban, para así evitar los errores comunes en las palabras mal utilizadas, (como el uso de "mientras", un adverbio de tiempo, cuando el escritor quiere decir: "mientras que o aunque", o el uso de "a través de", un adverbio de movimiento a través de espacios físicos, cuando el escritor quiere decir "por medio de" o "con". Cuando los estudiantes adquieren estos y otros medios de escritura más precisa, el curso les proporciona los medios para variar la estructura de la oración más allá de la utilizada por los escritores intermedios hábiles (sustantivo + verbo + objeto y verbo + objeto), para producir oraciones cada vez más precisas, de causalidad, temporales y relaciones de subordinación y de comunicación interesantes y, por lo tanto, más eficaces, por ejemplo, el cambio de: "El ingeniero quería crear un fuselaje ligero, él utilizó nuevos compuestos", a "El ingeniero, quería crear un fuselaje ligero, empleando nuevos compuestos", o "Cuando el ingeniero quería crear un fuselaje más ligero, que emplea nuevos materiales compuestos". Ambos profesores observaron que, aunque frecuentemente se hizo énfasis en la discusión en clase, la escritura no mejoró como se esperaba en la Wiki. 
Tema: Nuevos Lenguajes y Educación

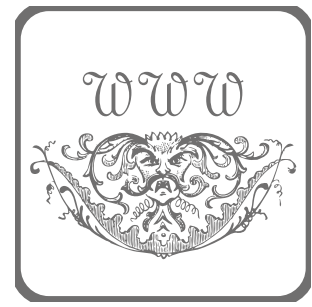

